\title{
Impact of Covid-19 Pandemic On Local Rice Supply Chain Flow Patterns In Kapuas Regency, Central Kalimantan, Indonesia
}

\author{
YUNI ERLINA \\ Agribusiness, Faculty of Agriculture, Palangka Raya University \\ Menteng V Street, Palangka Raya, Central Kalimantan \\ INDONESIA \\ EVI FERONIKA ELBAAR \\ Agribusiness, Faculty of Agriculture, Palangka Raya University \\ Palangka Raya, Central Kalimantan \\ INDONESIA
}

\begin{abstract}
The fact that the pandemic condition due to Covid-19 that broke out in early 2020 has caught the attention of various elements of society. The visible impact is not only on public health, but also influences the distribution and availability of various food supplies, especially local rice in the study area. The purpose of this study was to examine the flow patterns of the local rice supply chain during the Covid-19 pandemic. Data analysis using supply chain analysis of Supply Chain management (SCM). The results of the analysis show that at the farmer / producer level it does not significantly affect farming activities, only 29.77 percent of farmers stated that there was an influence on farming activities. The impact of Covid-19 mainly affects the level of intermediary institutions in the rice distribution process. Long product (material) flow patterns by business actors need to be shortened by a short distribution route. Another effect is the inaccuracy of product arrival time due to delays in the inspection process for products brought to the research location. The impact of Covid-19 is mainly felt by distributors / wholesalers who flow products to other areas, mainly due to the increase in additional costs related to Covid-19 requirements. The solution to integrate all SCM elements through an information system can facilitate the flow pattern of local rice in Kapuas District, by intensifying the management of information related to production at the producer level, as well as controlling rice supplies at the level of intermediary institutions.

Keywords: Covid-19 pandemic, local rice, supply chain, materials, informations, financial

Received: October 15, 2020. Revised: May 25, 2021. Accepted: May 28, 2021. Published: June 1, 2021.
\end{abstract}

\section{Introduction}

As a country where most of the population lives in the agricultural sector, food selfsufficiency by emphasizing local potential is a very important and strategic issue to raise. This is also in line with the spirit of regional autonomy which focuses on efforts to develop food self-sufficiency based on local resources and wisdom rooted in the community [1].

Kapuas Regency is one of the districts in Central Kalimantan which is a rice/rice producer. In addition, Kapuas Regency has long been proven to be a rice granary for the Central Kalimantan Province [7] [8].

Rice production in Kapuas Regency is the highest production, and it is hoped that it can continue to be increased even in the midst of the outbreak of the corona issue, so that it is not only able to provide for the Central Kalimantan region, but can also be marketed outside the Central Kalimantan region, in order to meet and anticipate food availability in a sustainable manner national [8].

The existence of location-specific local rice is still cultivated and maintained for the cultivation of the farmer household [10] [11] [17]. With the Covid-19 pandemic it is not known to what extent it has an impact on the distribution patterns of local rice circulating in the research area when viewed from a marketing perspective.

The pandemic condition due to Covid-19 which is present in the midst of society in 2020 has attracted the attention of various elements of society. The visible impact is not only on public 
health, but also influences the distribution and availability of various food supplies, especially local rice in the study area.

Local rice produced from location-specific rice products is widely circulated and sold in the market [7][8]. It is even interesting that local rice prices are on average more expensive than rice originating from the island of Java, but even though the price is expensive, many consumers still consume local rice, this is interesting for researchers to know more about this phenomenon and its impact on the conditions of the Covid-19 pandemic. This raises the researchers curiosity, what are the supply chain management institutions for local rice products produced by farmer households in Kapuas District? What is the flow pattern of the local rice supply chain during the Covid-19 pandemic in Kapuas Regency, Central Kalimantan? Based on this background, the purpose of this study is to examine the flow of local rice during the Covid19 pandemic, in Kapuas Regency.

\section{Problem formulation}

The Research Team is interested in conducting research related to products produced from local wisdom of food crop farming carried out by farmer households from upstream to downstream of the local rice supply chain process in Kapuas District, Central Kalimantan Province. Thus, based on the description above, it is related to the supply chain of local rice products to support regional food in Central Kalimantan, so it can be formulated to what extent the Covid-19 pandemic has an impact on the performance of local rice agribusiness and a description of the local rice supply chain in Kapuas District, Central Kalimantan. The above problems have become an important issue lately in maintaining the sustainability of local rice products which are a source of support for the farmer household economy, in order to keep the local rice distribution chain running smoothly even in the midst of the Covid-19 pandemic [6] [15], and remain sustainable and in accordance with the symptoms that occur in society, conditions and local wisdom community local [4].

\section{Research methods}

The research is focused in Kapuas District, Central Kalimantan Province, the study was implemented from April to August 2020, with the object of research being farmers / farmer groups, rice mills, suppliers and other institutions involved as an agribusiness system so that the product reaches the end consumer. The research method was carried out by survey methods. Furthermore, the determination of the number of respondents starting from farmers / farmer groups, rice mills, middlemen / suppliers, which in this study was determined using the snowball sampling method. The snowball sampling method is a method where respondents are obtained through a rolling process from one respondent to another or through a linkage in a network. Snowball sampling is an approach to finding key informants who have a lot of information. The total number of respondents as a whole is 69 respondents, consisting of 35 farmers, 7 owners of rice mills, 6 collectors, 4 distributors, 4 wholesalers, 13 retailers. Analysis using supply chain structure analysis of Supply Chain management (SCM) [13] [14] [19], described in a descriptive qualitative manner by synchronizing and coordinating activities related to the flow of local specific rice products.

\section{Results and interpretation}

\subsection{Characteristics of local rice supply chain producers}

Producers / farmers are in the productive age, namely the dominant age group 40-55 years as much as 71.43 percent. The education level of the head of the respondent farmer family is on average primary school (SD), and the second level of education is SLTP. Based on data obtained from respondent farmer households, the number of workers available in the household is between 3-4 people. On average, respondents have 10-20 years of experience managing their farms, which is 54.29 percent of the total respondents. The average area of land cultivated by farmers to be planted and cultivated by 
farmers of superior rice and local varieties is 44.21 borong or if converted to hectares is 1.26 hectares, from a planting area range of 35-64 borong or between $1-1.8$ ha. The average types of seed varieties planted in Kapuas Regency are for local rice seeds, namely Siam Unus, Siam Pandak, Siam Mutiara, Mayang, and Karang Dukuh. At the time of the research, the average GKP production volume of farmers was $2,721 \mathrm{~kg}$ / ha or an average of 3,428.46 per land area. Meanwhile, the average price of harvested dry grain is Rp. 6,982 per $\mathrm{kg}$ of GKP. An average of 65-75 percent of farmers' grain is sold.

\subsection{Characteristics of actors / intermediaries in the local rice supply chain}

The characteristics of rice mill owners (RMU) and intermediary traders at the research location, the average age of rice mill owners (RMU) is 4055 years old, has an average high school education, the average number of family members is 2-4 people, and has experience managing mills for a long time, namely more than 15 years or 85.71 percent.

When viewed from the characteristics of the merchant collectors, the average age of the merchant collectors is also an average age of 4055 years, has an average high school education, the average number of family members is $2-4$ people, and has quite a long trading experience which is also more of 15 years or 66.67 percent.

Distributors have an average age ranging from 40-55 years, have an average high school education, average family members are 2-4 people, and have more than 15 years of business experience. This means that the distributors are very experienced in doing their profession.

Wholesalers have an average age range of 4055 years, have an average high school education, average 2-4 family members, and have more than 15 years of business experience. This means that the big traders are very experienced in managing their businesses.

Characteristics of retail traders, average age 20-39 years, average junior high school education, average number of family members 2-4 people, and have quite a long experience in managing mills, namely more than $11-15$ years or 46,15 percent.

\subsection{Local rice supply chain Flow patterns suring the covid-19 pandemic}

The Covid-19 pandemic has an impact not only on health, but also on all areas of community life, including research areas. Based on the results of research and interviews with respondents at the farmer level, that the impact of Covid-19 at the farmer level on rice farming activities was almost 70.23 percent of farmers stated that at the beginning of the outbreak of news related to the pandemic (December 2019 to mid-March 2020) there was no apparent effect. There was a significant effect on rice farming activities in the study area, the remaining 29.77 percent of farmers stated that there was an effect, especially on the reduction (there was no prohibition) on the intensity of gathering in farmer group activities.

The effect of Covid-19 was evident when entering the end of March and early April 2020, in addition to reducing the time to gather, the impact, especially on planting time, was due to difficulties or disruption in the distribution of agricultural production facilities. As many as 29.77 percent of farmers stated that the impact of Covid-19 had an effect on the distribution of input products, especially on the availability of fertilizers and medicines needed by farmers, while seeds had no effect, because farmers always had seeds available for the next planting season. Even so, farmers continue to carry out activities as usual even though there are still concerns about Covid-19.

As stated in the theory that the Supply Chain is a series of relationships between business actors who carry out the distribution of supply of products or services from the place of origin to the buyer or customer [2] [9]. Supply chain involves a continuous relationship regarding products, money, and information [3] [20]. Products generally flow from upstream (upstream) to downstream (downstream), money flows from downstream to upstream, while information flows from both upstream and downstream to upstream.

The influence of the Covid-19 pandemic on the distribution of agricultural output is mainly felt by rice milling businesses and intermediary traders, both collectors, wholesalers/ distributors, to retailers and consumers related to 
the distribution of rice supply [16]. The flow pattern of the local rice supply chain is presented in Figure 1.

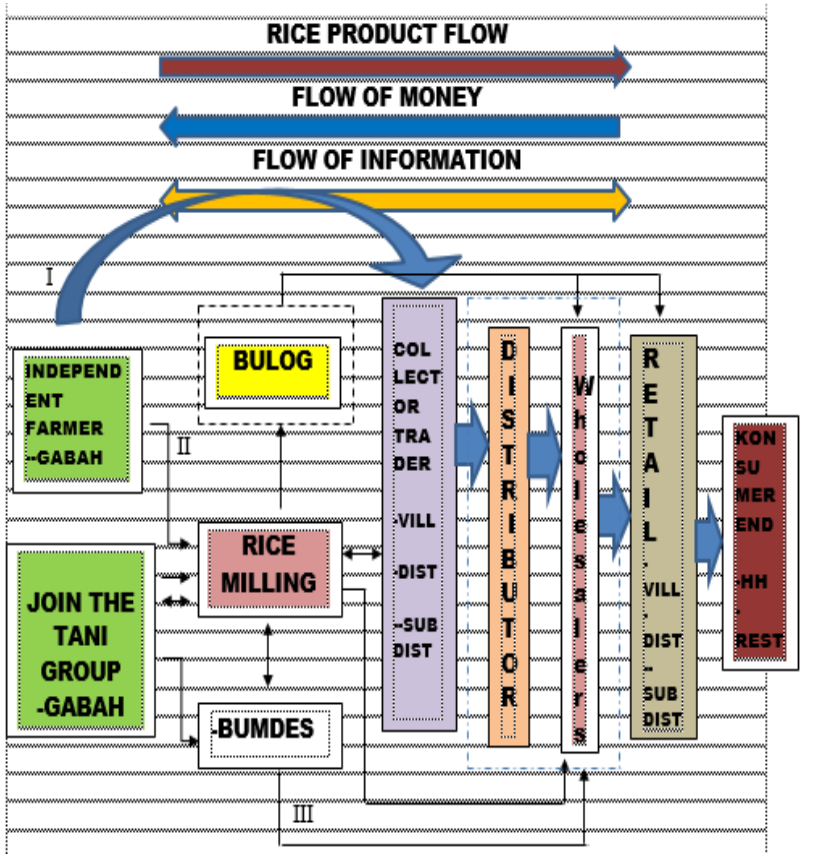

Figure 1. Flow Patterns and Supply Chain Actors of Grain and Rice in Kapuas Regency, 2020

Source: Primary Data, (2020)

\section{Product flow, finance, and supply chain information I}

Referring to the scheme in Figure 1, it can be explained that the flow pattern of the product supply chain is that farmers independently distribute production starting from farmers and sell to collectors in villages and sub-districts. The farmers' average sales are sold to collectors with the same grain classification. The total purchase by collectors is 2.5 tons to 7.5 tons of unhulled rice, by the collecting traders, then milling is carried out and then sold to wholesalers and transported to warehouses by pick-up and / or truck.

The volume of grain sales by farmers ranges from 65-75 percent of the grain allocated for sale by each farmer. Even though the volume sold by farmers is small, if the type of product sold is the same, it is still purchased by collectors. Not all unhulled rice produced by farmers is sold, farmers who have a large enough land, the largest part of the production is sold, but farmers who have small land only to meet household needs. During the Covid-19 period, the sales volume of farmers did not change much as in normal conditions, this was due to the belief that farmers would still need products by all groups, which were not the same as other products.

The financial transactions are mostly cash payments, because rice products are now added in the Covid-19 condition, farmers do not want any debt or credit in buying and selling, as well as buyers. Buying and selling is done in cash [26], although usually in normal conditions, payment transactions can be made 2 payment stages with a payment range of 1 week later, but due to Covid, farmer producers do not want risk coverage.

Information and communication is done via cellphone or through farmer groups. Basically, among the farmers there is already a sale and purchase communication network, so that the buying and selling system is formed by itself. In the condition of Covid, the information problem faced is that it is difficult to predict this due to the increasingly busy use of cellphones and the increasing cost of pulses or data packages from previous normal conditions.

The impact of Covid-19 on product flow patterns mainly affects the rice distribution process [25]. The long product flow pattern by business actors is shortened by a short distribution route [2] [21] [22] [24]. Another effect is the inaccuracy of product arrival time due to delays in the inspection process for products that are brought when passing through the cross-city flow checkpoints at the research location. The impact of Covid-19 is mainly felt by distributors / wholesalers who distribute products especially to other areas (Banjarmasin-Palangka Raya) during the implementation of the PSBB (LargeScale Social Restrictions), this is due to the increase in additional costs in the form of rapid test letters of IDR 550,000 / person (happened at the start of the pandemic). This increase in costs is certainly a burden for traders who flow rice products out of the region.

\section{Product flow, finance, and supply chain information II}

In Figure 1, the flow pattern of supply chain products there are farmers who sell produce to 
rice milling. The produce is sold in the form of dry grain. Then the mill cooperates with the collector trader and then continues the distribution of products in the form of rice to the large traders who are at the district level.

Farmers who sell their products in the form of unhulled rice are farmers who do not have adequate transportation facilities to sell their products, so they sell their products in the form of unhulled rice, besides farmers who do not bother to do the rice milling process. On the one hand, farmers who do not have transportation facilities find it helpful to sell their produce.

The sales volume of dry unhulled rice by each farmer to the rice mill averaged $1,750 \mathrm{~kg} /$ ha per one planting season sale according to the production allocated for sale by each farmer. It is the same with chain I, although the volume sold is small, if the type of unhulled rice is sold, it is still purchased by collectors. During the Covid19 period, the sales volume of farmers did not change much as in normal conditions.

Similar to chain I, the average financial transaction is cash payment, because for grain products, farmers and buyers do not want any debt or credit in buying and selling. Buying and selling is done in cash. Information and communication is done via cellphone or via farmer groups. Basically, among the farmers there is already a sale and purchase communication network, so that the buying and selling system is formed by itself.

\section{Product flow, finance, and supply chain information III}

In Figure 1, the product supply chain flow pattern is a combination of farmers who sell their products to BUMDes (Village-Owned Enterprises). Products are sold in the form of dry unhulled rice. BUMDes is functioned to accommodate rice from farmers. Then BUMDes collaborates with rice mills and partners with large traders at the district level.

Similar to the supply chain II, farmers who sell their products in the form of unhulled rice are farmers who do not have adequate means of transportation to sell products in large enough quantities, so that they sell their products in the form of unhulled rice, besides the farmers are not bothered and practical and no need to do the grinding process.

The sales volume of dry unhulled rice by farmers to rice mills ranges from $500-1,500 \mathrm{~kg}$ per sale according to the production allocated for sale by each farmer. It is the same with chain I, although the volume sold is small, if the type of grain being sold is the same, BUMDes will still buy it. During the Covid-19 period, the sales volume of farmers did not change much as in normal conditions.

Similar to chains I and II, the average financial transaction is cash payment, buying and selling is done in cash. Information and communication is done via cellphone or through farmer groups [12]. Basically, among Gapoktan there is already a sale and purchase communication network, so the buying and selling system is formed by itself. Still referring to Figure 1, the product supply chain flow pattern is a combination of farmer groups working together to grind unhulled rice in a rice mill, then collaborating with Bulog. This pattern is mostly used for superior varieties of rice products because handling can be done quickly. Gapoktan collaborates with Bulog and makes a supply contract, then Bulog carries out the packaging and product labeling process according to grade. Bulog then collaborated with large traders at the district level in terms of distributing rice.

Gapoktan manages the products produced by farmers according to the volume produced by group members. On one hand, this pattern is very helpful for farmers who do not have adequate means of transportation to sell their products. However, this pattern also has a weakness at the Gapoktan level, namely the pattern of payment transactions that cannot be done in cash, while farmers on average want the transaction process to be done in cash. Gapoktan is still limited to locally owned and rotated means of transportation. This pattern can be developed even better, so that farmers can carry out activities without obstacles. Information and communication is done via cellphone or through farmer groups. 


\section{Conclusions}

The results of this study are an introduction to research that can be used as a reference for further research on the structure of local rice flow patterns. The importance of this article is to point to better changes related to the performance of local rice agribusiness and the impact of Covid-19 on the flow patterns of the local rice supply chain in the study area.

The flow pattern of the local rice supply chain during the Covid-19 pandemic consisted of product flows, money flows and information flows. At the farmer level, the impact of Covid19 did not significantly affect farming activities, only 29.77 percent of farmers stated that there was an effect, especially on reducing the intensity of gathering in farmer group activities. Financial transactions The impact of Covid-19 is cash payments. Information and communication is done via cellphone or through farmer groups. In the Covid condition, the information constraints faced are difficulty in signals and swelling of the cost of pulses or data packages from previous normal conditions. The impact of Covid-19 mainly affects the level of traders in terms of the rice distribution process. The long product flow pattern by business actors is shortened by a short distribution route. Another effect is the inaccuracy of product arrival time due to delays in the product inspection process at the research location. The impact of Covid-19 is mainly felt by distributors/wholesalers who distribute products to other areas (BanjarmasinPalangka Raya), mainly due to the increase in additional costs in the form of rapid test letters during the implementation of the PSBB and other requirements related to Covid- 19 .

The local rice supply chain institution is considered very long. Due to limitations in processing facilities, farmers as producers are more likely to sell in the form of unhulled rice due to limited equipment owned both in transportation and in processing. Therefore, to increase the share of yields received by farmers, it is hoped that the government can assist farmers in post-harvest equipment for farmer groups, so that the share received by farmers is higher. In order to reduce the risk caused by Covid-19, especially in intermediary institutions, the government or related agencies can ensure the continuity of local rice distribution from the farmer / producer level to the final consumer.

\section{ACKNOWLEDGMENT}

The research team would like to thank the Institute for Research and Community Service through the 2020 DIPA PNBP Palangka Raya University for funding this research.

\section{References:}

[1] Arsyad D.M., Saidi B.B., dan Enrizal, (2014). Pengembangan Inovasi Pertanian Di Lahan Rawa Pasang Surut Mendukung Kedaulatan Pangan. Balai Besar Pengkajian dan Pengembangan Teknologi Pertanian. Jurnal Pengembangan Inovasi Pertanian Vol.7 No. 4. pp 169-176. Bogor.

[2] Bazzani C., Canavari M. (2013): Alternative agri-food networks and short food supply chains: a review of the literature. Economia agro-alimentare, 24: 11-34.

[3] C. R. Carter, P. L. Easton, Sustainable Supply Chain Management: Evolution and Future Directions, International Journal of Physical Distribution \& Logistics Management, Vol. 41, No. 1, 2011, pp 46-62.

[4] Deni Daniel Kesa dan Cheng Wen Lee, (2013). Kebijakan Sektor Pertanian sebagai Awal kebangkitan Ekonomi Studi Kasus Taiwan Dalam Mengelola Komoditas Padi. Jurnal Vokasi Indonesia. Vol. 1, Nomor 1, pp 43-73.

[5] Donthu N., Gustafsson A., 2020. Effects of COVID-19 on business and research. Journal of Business Research. Vol.117, pp. 284-289.

[6] Elmira N., G., Satya S., and Alec C., 2017. Case Study Analysis of Sustainable Supply Chain Redesign Linking with New Product Development. WSEAS Transactions On Business and Economics. Vol. 14, 2017, pp 193205.

[7] Erlina Y., (2010). Analisis Usahatani Padi Varietas Unggul dan Lokal Pada Lahan Gambut di Kabupaten Kapuas. J-SEA (Journal Socio Economics Agricultural) (Sosek - Unpar) Edisi Agustus 2010 ISSN 1693-4784.

[8] Erlina Y., Elbaar E.F., Wardie J., 2021. Strategi Pengembangan Padi Lokal Spesifik Lokasi Di Kabupaten Kapuas Provinsi Kalimantan Tengah. Agribusiness and 
Agricultural Socio-Economics (AGRISEP). Vol. 20; Nomor 1; Maret 2021; Hal: 12-24.

[9] Fondse M., Wubben E.F., Kortstee H., Pascucci S. (2012): The economic organizations of short supply chains. In: New challenges for EU agricultural sector and rural areas. Which role for public policy? Proceeding of the 126th EAAE Seminar, Capri, June, 27-29, 2007.

[10] Gardner, B. L., and Gordon C., Rausser, (2001). Handbook of Agricultural Economics. Elsevier. Amsterdam-London-New YorkOxford -Paris-Shannon-Tokyo.

[11] Gaviglio A., Demartini E., Mauracher C., Pirani A. (2014): Consumer perception of different species and presentation forms of fish: An empirical analysis in Italy. Food Quality and Preference, 36: 33-49.

[12] Hardesty S.D., Leff P. (2010): Determining marketing costs and returns in alternative marketing channels. Renewable Agriculture and Food Systems, 25: 24-34.

[13] Indrajid R.E., Djokopranoto R., (2002). Konsep Management Supply Chain: Cara Baru Memandang Rantai Penyediaan Barang. Jakarta: Grasindo, PT Gramedia Widiasarana Indonesia. [14] Kaplinsky, R., and M. Morris., (2001). A Handbook for Value Chain Research. Brighton: Instutute of Development Studies. University of Sussex.

[15] Kuntoro Boga Andri, (2012). Analisa Manajemen Rantai Pasok Agribisnis Tembakau Selopuro Blitar Bagi Kesejahteraan Petani Lokal. Seminar nasional: Kedaulatan Pangan dan Energi, Juni 2012. Universitas Trunojoyo Madura.

[16] McGinnis, M.A. and Vallopra, R.M., (1999). "Purchasing and supplier involvement in process improvement a source of competitive advantage". Journal of Supply Chain Management.Vol. 35 No. 4, pp. 42-50.

[17] Nowak A., Kaminska A. (2016): Agricultural competitiveness: The case of the European Union countries. Agricultural Economics - Czech, 62: 507-516.

[18] Pantano E., G. Pizzi, Scarpi D., Dennis C., 2020. Competing during a pandemic? Retailers' ups and downs during the COVID-19 outbreak. Journal of Business Research. Vol. 116, pp. 209-213.
[19] P. Hilletofth, D. Eriksson, Coordinating New Product Development with Supply Chain Management, Industrial Management \& Data System, Vol. 111, No. 2, 2011, pp 264-281.

[20] Renting H., Marsden T.K., Banks J. (2003): Understanding alternative food networks: exploring the role of shortfood supply chains in rural development. Environmentand planning A, 35, pp 393-412.

[21] Robert D., Dariusz T., and Anna O.D., 2020. Distribution of Services Within The Call Center and Covid 19-A Case Study. WSEAS Transactions On Business and Economics. Vol. 17, 2020, pp 921-932.

[22] R. Van Hoek, P. Chapman, From Tinkering Around The Edge To Enhancing Revenue Growth: Supply Chain Management: An International Journal. Vol. 11, No. 5, 2006, pp 385-389.

[23] Saptana, Daryanto A., (2012). Manajemen Rantai Pasok (Supply Chain Management) Melalui Strategi Kemitraan Pada Industri Broiler. Dalam: Bunga Rampai Rantai Pasok Komoditas Pertanian Indonesia. Eds. Erna Maria Lokollo. IPB Press. Bogor.

[24] Szabo L., Zsarnoczai J.S. (2004). Economic conditions of Hungarian agricultural producers in 1990s. Agricultural Economics - Czech, 50, pp 249-254.

[25] T. Williams, R. Maull, B. Ellis, Demand chain Management Theory: Constraints and Development from Global Aerospace Supply Webs. Journal of Operations Management. Vol. 20. No. 6, 2002, pp. 691-706.

[26] Walasek R., Zimon G., 2020. The Analysis of Financial Liquidity Management In Small Transport Enterprises During The Covid 19 Pandemic-Case Study of Poland. WSEAS Transactions On Business and Economics. Vol. 17, pp 786-795.

\section{Contribution of individual authors to the creation of a scientific article (ghostwriting policy)}

Yuni Erlina, Evi Feronika Elbaar-Conceptualization Yuni Erlina, Evi Feronika Elbaar-writing-reviewediting and analysis Yuni Erlina-original draft preparation 


\section{Creative Commons Attribution}

License 4.0 (Attribution 4.0

International, CC BY 4.0) This article is published under the terms of the Creative Commons Attribution License 4.0

https://creativecommons.org/licenses/by/4.0/deed.en _US 